\title{
Applying Simulation for Oil and Gas Industry Case Albpetrol Company
}

\author{
PhD. Blerta Mjeda \\ Department Applied Statistics and Informatics, \\ Economic Faculty, University of Tirana
}

Doi: 10.2478/ajis-2018-0070

\begin{abstract}
The overall subject for this paper is to enlarge our understanding of simulation behavior while working in investment projects, taking as example the Albpetrol oil production company. An understanding of simulation behavior is essential, since human resources should be regarded as competitive strengths for organizations competing in an international market. The objective of this evaluation is to understand if this investment project has a good chance to be implemented, and to be undertaken as a project, or if the chances are lower. Taking into accountant the importance of oil and gas industry today we should offer the better conditions and better services in order to survive the competition and this is possible if we are doing a good research. For years the company has taken into consideration the possibility of drilling new wells, serving in the existing deposits where it is carrying out its activity. for this purpose, all the data on these deposits have been analyzed and studied, and it has already been concluded that Albpetrol could launch new wells in the fields such as Cakran-Mollaj, Amonice and Patos-Marinze.
\end{abstract}

Keywords: modeling and simulation, projects investments, methods of analyzing

\section{Introduction}

Oil Industry over years played an important role in establishing equitable balances both in development of the economy and the development of political one, around the world.

This wealth has supported and supports all development programs in Albania. The Albpetrol Company is owned by the Ministry of Infrastructure and Energy, and the shares are owned 100\% by the State.

\section{Methodology}

In this research data are taken from the Albpetrol Company. It is emphasize that in the sources that the Albpetrol Company administers today, most wells are utilized with existing oil extraction technology with piston and convex pumps, as the most remote and highly amortized technology, however these reserves have technological reserves that can the efficiency of the classical technical work, though it has high costs and has limited ability to increase oil production, will be one of the working directions for increasing oil production;

$>$ Forecasting the probability distribution of the NVP in the Albpetrol Oil Production.

$>$ Exploring the cost structure of the investment project for the Albeprotl Oil Company, cost inputs and its main output.

$>$ Time is required on scheduling an investment project in Albpetrol Oil Production, for completing each task of the project. 


$\begin{array}{lc}\text { Recovery Size } & 1500 \mathrm{mmbbls} \\ \text { Recovery } & 42 \% \\ \text { Time to plateu } & 2 \mathrm{Years} \\ \text { Well rate } & 10 \mathrm{mbd} \\ \text { Wells to drill } & 25 \\ \text { Minimum rate } & 10 \mathrm{mbd} \\ \text { Discount factor } & 10 \% \\ \text { Well cost } & 10 \$ \mathrm{~mm} \\ \text { Facility size } & 250 \mathrm{mbd} \\ \text { Oil margin } & 2 \$ / \mathrm{bbl} \\ \text { Plateau ends at } & 65 \% \text { of reserves } \\ \text { Plateau rate is } & 10 \% \text { of reserves annnually }\end{array}$

Figure 1. Input variable of Albpetrol Oil production

Source: www.albpetrol.al

Table 1.The Explanation of the Abbreviations used.

\begin{tabular}{|ll|}
\hline & Abbreviations Used \\
\hline mmbbls: & million barrels \\
mbd: & thousand barrels per day \\
$\$ \mathrm{~mm}:$ & million dollars \\
$\$ / \mathrm{bbl}:$ & dollars per barrel \\
\hline
\end{tabular}

Source: www.albpetrol.al

\section{Analyzing Research Projects}

The main idea of this research is to get to the better outlook about the future using several techniques. Oil production in industry faces with uncertainty and risk analyses.

Finishing the project and scoring the drilling value may require reallocations or changes in the investment program of Albpetrol. Therefore a simulation analysis is required.With very little actual data, Alpbetrol Company wants to forecast the oil.

\section{Methods of Risk Analysis in Albpetrol Oil Production}

There are methods how to determine the profit and loss in the Albpetrol Oil Production, if we want to know if is a good project or not we have to calculate the Net Present Value, for the reserves, plateau rate, wells to drill, facility size.

\section{Results}

From the spreadsheet in excel, through the steps, we have the calculation as below:

\begin{tabular}{|l|r|}
\hline Reserves & 630 \\
\hline Max plateau rate & 172.6027 \\
\hline Plateau rate & 172.6027 \\
\hline Build up production & 63 \\
\hline Plateau production & 346.5 \\
\hline Plateau ends at & 7.5 \\
\hline Decline factor & 0.269161 \\
\hline Production life & 18.08254 \\
\hline
\end{tabular}

Figure 2. Calculated value of the Albpetrol Company

Source: Own 
Step1. Reserves is calculated with the formula $\mathrm{C} 4{ }^{*} \mathrm{C} 5 / 100$, taking into consideration recovery size and recovery.

Step2. Max plateau rate is calculated with the formula $(\mathrm{C} 15 / 100){ }^{*} \mathrm{C} 18 / 0.365$, where $\mathrm{C} 15$ is plateau rate and $\mathrm{C} 18$ is reserves.

Step3. Plateau rate is calculated with the formula MIN $\left(\mathrm{C} 19, \mathrm{C} 7{ }^{*} \mathrm{C} 8, \mathrm{C} 12\right)$ where $\mathrm{C} 19$ is the Max Plateau rate, C7 is Well rate, $\mathrm{C} 8$ is Wells to drill, and C12 is Facility size.

Step4. Build up production is calculated with the formula $0.365^{*} \$ C 20^{*} 0.5^{*} \$ C \$ 6$.

Step5. Plateau production is calculated with the formula $\operatorname{MAX}\left(0, C 14^{*}(C 18 / 100)-C 21\right)$ where C14 is Plateau ends at, C21 is Build up Production, C18 is Reserves.

Step6. Plateau ends at is calculated with the formula C22/ $\left(0.365^{\star} \mathrm{C} 20\right)+\$ C \$ 6$ where $\mathrm{C} 22$ is Plateau Production and C20 is Plateau rate.

Step7. Decline factor is calculated with the formula 0.365 * (C20- C9) / (C18- C22 - C21) where C20 is Plateau rate, C9 is Minimum rate, C18 is Reserves, C22 is Plateau Production, C21 is Build up Production.

Step8.Production Life is calculated with the formula:

IF (C9>0, C23-LN (C9/C20)/C24, 10^20) where C9 is Minimum rate, C23 is Plateau ends at, C20 is Plateau rate, C24 is Decline factor.

Step9. Discounted Reserves is calculated with the formula F85, where this is taken from the table Calculated Production Profile from the Cumulative Discounted Oil.

Step10.Well Costs is calculated with the formula $\mathrm{C} 11^{*} \mathrm{C} 8$ where $\mathrm{C} 11$ is well costs, and $\mathrm{C} 8$ is Well to Drill.

Step11.Facilities Costs is calculated with the formula VLOOKUP (C12, F20:G26, 2) where $\mathrm{C} 12$ is the Facility Size, F20 is the Facility output, G26 is the Facility cost.

Step 12.Net present Value is calculated with the formula $\mathrm{C} 27^{*} \mathrm{C} 13-\mathrm{C} 28-\mathrm{C} 29$ where $\mathrm{C} 27$ is the Discounted Reserves, C13 is the Oil Margin, C28 is the Well costs, C29 is the Facilities Costs.

Table 1: Calculated the NPV

\section{Source: Own}

\begin{tabular}{|c|c|c|}
\hline Discounted Reserves & 379.45 & mmbbls \\
\hline Well Costs & 250.00 & $\$ \mathrm{~mm}$ \\
\hline Facilities Costs & 250.00 & $\$ \mathrm{~mm}$ \\
\hline NPV & 258.89 & $\$ \mathrm{~mm}$ \\
\hline
\end{tabular}

Step 13.Annual Production $(\mathrm{mmb})$ is calculated with the formula:

$\operatorname{IF}(\mathrm{B} 36<\$ C \$ 6+1, \mathrm{~B} 36 * 0.365 * \$ C \$ 20 /(\$ C \$ 6+1), 0.365 * \$ C \$ 20 *(\mathrm{MAX}(0, \mathrm{MIN}(\$ C \$ 23+1-$ $B 36,1))+\left(E X P\left(-\$ C \$ 24^{*} \operatorname{MAX}(0, \operatorname{MIN}(\$ C \$ 25, B 36-1)-\$ C \$ 23)\right)-E X P(-\$ C \$ 24 * \operatorname{MAX}(\operatorname{MIN}(\$ C \$ 25, B 36)-\right.$ $\$ C \$ 23,0)) / \$ C \$ 24)$ ). Here it is changing only the number of the cell. Production decline rate is exponential with the exponent calculated to produce remaining reserves.

Step14. Annualized Rate ( $\mathrm{mbd}$ ) is calculated with the formula: D36/0.365. Here it is changing only the number of the cell.

Step15. Cumulative oil $(\mathrm{mmb})$ is calculated with the formula D36, taken from the Annual Production $(\mathrm{mmb})$ row. The cell 37 is calculated with the formula E36+E37. This is going cumulative till the year 50 .

Step 16.Cumulative Discounted oil $(\mathrm{mmb})$ is calculated with the formula E36 taken from Cumulative Oil $(\mathrm{mmb})$ row. The cell 37 is calculated with the formula F36+D37/ $\left(\left(1+0,01^{*} \$ 10\right)\right.$ $\left.{ }^{\wedge} \mathrm{B} 36\right)$. Here it is taken into consideration the year for each cell.

\section{Conclusions}

We find it really useful and efficient using the simulation for taking a better decision for Albpetrol Oil Development.

In the future direction we can say that Albpetrol Company by using the simulation techniques when all the process is done, the analyst can decide whether to continue or ask for other results 
from other methods.

It helps the analyst to maximize the NPV and minimize the cost in an oil production.

\section{References}

Betty Simkins January 7, 2010 "Enterprise Risk Management: Today's Leading Research and Best Practices for Tomorrow's Executives" Hardcover - faqe 420-465

Brah, M., Real Options in Practice. John Wiley \& Sons, Hoboken, New Jersey, 2003.

C. Dennis Pedgen, Randall P, Sadowski, Robert E. Shannon, March 2005 "Introduction to Simulation Using Simon" $2^{\text {nd }}$ edition Faqe 33-57

Haario Heikki, Turunen Ilkka, 26-27 October 2000"Mathematical aspects in the modeling of novel unit processes, Centre for Process Systems Engineering workshop" London faqe 5.

Haataja Juha, October, 2000"The ten most important algorithms of the century, CSC News", Vol.12, No.3. faqe 15

Hubbard, Douglas, 2009. The Failure of Risk Management: "Why It's Broken and How to Fix It ". p. 46.

George Fishman, 2000, "Monte Carlo" faqe 112-150, 204-233, 404-436

Michael J. Economides, A. Daniel Hill, Christine Ehlig-Economides, Ding Zhu October 5, 2012 "Petroleum Production Systems" (2nd Edition) faqe 12.

Michael B. Miller December 31, 2013 "Mathematics and Statistics for Financial Risk Management" Hardcover faqe 274

Oakshott, L., 2007 „Business Modelling and Simulation”. Pitman Publishing, faqe 547-575

Rose, Jan. 2009, "Dealing With Risk and Uncertainty in Exploration: How Can we Improve?" AAPG Bulletin 71, No.1,faqe 46-62.

Industria e Naftës dhe gazit në Shqipëri Buletin Shkencor (2002).

www.bankerspetroleum.com

www.albpetrol.al 